\title{
PHYSICAL AND CHEMICAL CHARACTERIZATION OF Melia azedarach L. FRUIT AND LEAF FOR USE AS BOTANICAL INSECTICIDE
}

\author{
Italo Chiffelle G. ${ }^{1}$, Amanda Huerta F. ${ }^{2 *}$, and Diego Lizana R. ${ }^{2}$
}

\begin{abstract}
A study was undertaken of the physical and chemical characteristics and insecticide properties of melia (Melia azedarach L.) (Meliaceae) fruit and leaves; melia has been introduced in Chile for ornamental purposes. The physical and chemical properties were evaluated in two stages of fruit and leaf maturity, i.e., green /mature, and mature/juvenile, respectively. Laboratory bioassays were carried out on Drosophila melanogaster Meigen (Diptera: Drosophilidae) as an insect model. The diameter of $M$. azedarach fruit was in the lower limit in relation to other studies. The flour obtained from green fruit had an average dry weight inferior to that of mature fruit. The average dry leaf weights were similar in both juvenile and mature states. The green fruits had $50 \%$ initial humidity, similar to juvenile $(60 \%)$ and mature $(57 \%)$ leaves, but greater than the mature fruits $(44 \%)$. The chemical analysis of the fruit maturity stages determined a slight increase in crude fiber content as maturity increased. There was a decrease in the lipid content of leaves close to $60 \%$ at maturity. Furthermore, an analysis of polyphenols was made using HPLC-DAD (High Performance Liquid Chromatography-Diode Array Detector), and 14 compounds were identified as causes of the insecticidal effect of the $M$. azedarach fruit, of which three would correspond to flavonoids: one catechin and two kaempherols. Finally, the aqueous fruit and leaf extracts of $M$. azedarach were effective insecticides on D. melanogaster, reaching $90 \%$ mortality $\left(125000 \mathrm{mg} \mathrm{kg}^{-1}\right)$ with juvenile leaves and $73.3 \%\left(10700 \mathrm{mg} \mathrm{kg}^{-1}\right)$ with green fruit.
\end{abstract}

Key words: Chinaberry tree, Meliaceae, phenolic compounds.

\section{INTRODUCTION}

Synthetic insecticides are important tools in pest control although they have been used excessively with negative consequences such as toxicity towards farmers, consumers, and wild animals, interruption of natural control and pollination, water pollution, and the evolution of resistance pests have acquired to these products (Perry et al., 1998). Botanical insecticides have been used in agriculture for at least two thousand years in Asia and the Middle East (Thacker, 2002). The interest for new botanical compounds for pest control is based on their bioefficiency, biodegradability, and physiological activity (Rodríguez, 1998; Isman, 1999).

Part of this study was presented at the 57th Chilean Agronomic Congress and the XXXIV Columbian Congress of Entomology.

${ }^{1}$ Universidad de Chile, Facultad de Ciencias Agronómicas, Av. Santa Rosa 11315, La Pintana, Casilla 1004, Santiago, Chile.

${ }^{2}$ Universidad de Chile, Facultad de Ciencias Forestales, Av. Santa Rosa 11315, La Pintana, Casilla 9206, Santiago, Chile.

*Corresponding author (ahuerta@uchile.cl).

Recibido: 10 September 2007.

Accepted: 24 April 2008.
The neem, Azadirachta indica A. Juss., and the Chinese neem, Melia azedarach L. (Meliaceae) are native trees of Asia and southern Australia with important insecticidal properties. Both species have been used mainly as ornamental trees and have been naturalized in tropical and subtropical countries (Villalobos, 1996). In Chile, melia is widely cultivated for ornamental purposes and has adapted well (Hoffmann, 1995).

The insecticide activity of $M$. azedarach is due to biologically active triterpenoids with an antialimentary effect, i.e., they inhibit the feeding of phytophage insects producing death and malformations of subsequent generations (Vergara et al., 1997; Carpinella et al., 2003). Leaf and fruit extracts have been evaluated on diverse pests with promising results (Padrón et al., 2003; Mazzonetto and Vendramim, 2003; Pérez-Pacheco et al., 2004).

The bioactivity of azadiractine (a tetranotriterpenoid) from $A$. indica has allowed to research natural insecticides in most similar types, including melia (González-Gómez et al., 2006). Within the triterpenoids in the M. azedarach seeds, meliacarpine, similar to azadiractine, is also active in the regulation of insect growth (Schmutterer, 2002). 
The main reason for the scarce development of $M$. azedarach as a commercial insecticide in comparison to $A$. indica lies in that the fruits of the former contain meliatoxin, a triterpenoid that is toxic for mammals (Schmutterer, 2002). However, the chemical composition of $M$. azedarach varies notably between its wild and cultivated state. The fruits developed in Argentina have triterpenoids instead of meliatoxin, mainly meliartenin which is a strong insect antialimentary that could be useful for pest and disease management (Carpinella et al., $2003 ; 2005)$.

Given the variability in the chemical composition of $M$. azedarach depending on the environment and management, this research was initially located in the central zone of Chile in order to study the physical and chemical characteristics of leaves and fruits in distinct stages of maturity, and test the insecticidal effectiveness of extracts originating from the said components of $M$. azedarach on D. melanogaster as an insect model.

\section{MATERIALS AND METHODS}

\section{Biological material}

The leaves and fruits of M. azedarach were randomly sampled from the crown of 15 heterogeneously mature

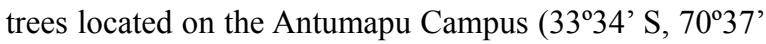
O) of the University of Chile in Santiago, Chile. Five kilograms of fruits were collected on April 12, 2006. The criterion for maturity was color and these fruits were separated as: juvenile (green) and mature (yellow). Three kilograms of mature leaves and juveniles were collected on June 15, 2006 and October 3, 2006 respectively. Color and consistency were the two criteria used to differentiate the state of maturity of the leaves: juvenile (light green and soft) and mature (dark green and coriaceous). The fresh leaf material was maintained refrigerated at $4{ }^{\circ} \mathrm{C}$ until it was analyzed.

Adult D. melanogaster were utilized as an insect model and fed in a breeding environment made up of a mixture of acid and water (1 L), agar agar (16 g), fine semolina (60 $\mathrm{g})$, dry yeast (10 g), methylparaben fungicide (Nipagin) $(12 \mathrm{~mL})$, sucrose $(43 \mathrm{~g})$, sodium nitrate $(4.2 \mathrm{~g})$, phosphate $(1.2 \mathrm{~g})$, potassium chloride $(0.7 \mathrm{~g})$, and magnesium sulphate $(0.7 \mathrm{~g})$ (Moreno et al., 2000).

\section{Physical measurement of fruits}

The weight (analytical scale, $0.1 \mathrm{mg}$ ) and diameter (vernier caliper, $\mathrm{mm}$ ) of the fruits were measured in the two stages of maturity $(\mathrm{n}=100)$ and the number of fruits per kilogram calculating the mean and standard deviation. The color of the fruit samples was determined, clearly differentiated and labeled using a colorimeter (Minolta CR 300, New York, USA) and the CIELab (Hunter
Labs, 1996) method, through a tristimulus measurement identifying the coordinates $\mathrm{L}^{*}$ : corresponding to clarity (from black to white); $a^{*}$ : spectrum from green to red; and $b^{*}$ : spectrum that oscillates between yellow and blue (Ngo et al., 2007).

\section{Chemical analysis of leaves and fruits}

The samples (1 kg each) of fruits (green and mature) and leaves (juvenile and mature) were dried in a forced air heater at $37^{\circ} \mathrm{C}$ during $65 \mathrm{~h}$. The fruits and leaves in their distinct states of development were ground separately in a mechanical mill with a $\mathrm{N}^{\circ} 60$ mesh graduated sieve and $0.25 \mathrm{~mm}$. A series of chemical characteristics of the states of maturity with the flours thus generated were studied and determined: lipids extracted with Soxhlet; raw fiber by means of acidic and basic hydrolysis; ashes from muffle incineration at $550{ }^{\circ} \mathrm{C}$; proteins through the micro-Kjeldahl method; the non-nitrogenated extract was obtained as the difference between the previous analyses and the humidity through drying in a forced air heater at $105^{\circ} \mathrm{C}$ until a constant weight was obtained (AOAC, 1984). All the analyses were done in triplicate thus obtaining the means with their respective standard deviations.

\section{Fruit polyphenol analysis}

An analysis was done of the fruit polyphenols in order to obtain the total tannins (Bate-Smith, 1981) as well as an itemized analysis of the low molecular weight polyphenolic compounds for the two states of maturity using individualization techniques for high efficiency liquid chromatography coupled to an aligned photodiode detector (HPLC-DAD) (Peña et al., 2000). High resolution liquid chromatography equipment was used (Merck Hitachi D-7000, Darmstadt, Germany), consisting in a pump (Intelligent Pump L-6200, Darmstadt, Germany), an automatic injector (Autosampler L-7200, Darmstadt, Germany), an aligned photodiode repair detector L7455 (Darmstadt, Germany), and a Waters Nova-pak $\mathrm{C}_{18}$ column with an internal diameter of $3.9 \mathrm{~mm}$ for a length of $300 \mathrm{~mm}$ for low molecular weight phenols.

The phenolic compounds were identified by comparing their absorption spectrum and retention time with their respective standard. Quantification was done utilizing the Sigma S.A. marker patterns: catechin, $p$-coumaric acid, ferulic acid, quercetin, epicatechin, kaempherol, gallic acid, (-) epicatechin, and the respective calibration straight lines (absorbency $280 \mathrm{~nm}$ ).

\section{Evaluation of the insecticidal of effectiveness of $M$. azedarach extracts}

Aqueous extracts were prepared with the M. azedarach leaf and fruit flours in two stages of maturity and three 
concentrations which were determined in accordance with the solubility of the flour in each solvent.

These M. azedarach extracts were evaluated by means of laboratory bioassays on D. melanogaster adults with distinct concentrations of the product. The acidic mixture to be fed to the insects was put into a glass jar $(300 \mathrm{~mL})$ with the extract produced from $M$. azedarach and the concentration defined for each treatment. Ten 5-day flies were introduced in the jars after the emergency which were permanently observed during 22 days; the dead and live flies were counted approximately every 2 days.

The analyses were done separately for each stage of maturity of the fruit and leaves. A completely random design with three repetitions was utilized. Three concentrations of the leaf and fruit extracts were used (25 000, 75000 and $\left.125000 \mathrm{mg} \mathrm{kg}^{-1}\right)$ and (3 200, 7500 and $10700 \mathrm{mg} \mathrm{kg}^{-1}$ ) respectively, as well as the pertinent controls (without extracts). A variance analysis of the results was done using the SAS version 6.11 statistical package (SAS Institute, 1998), and the means were compared with the Tukey tests $(\mathrm{p} \leq 0.05)$.

\section{RESULTS AND DISCUSSION}

\section{Physical characterization of the fruit and leaf}

The fruits showed a mean weight and diameter of $5.20 \pm 0.19 \mathrm{~g}$ and $14.0 \pm 0.5 \mathrm{~mm}, 4.06 \pm 0.10 \mathrm{~g}$ and 12.8 $\pm 0.5 \mathrm{~mm}$ for the green and mature stages respectively. The diameters of the fruits registered in this study were inferior to the $15 \mathrm{~mm}$ mean pointed out by Hoffmann (1995) (Table 1).

The mature fruit demonstrated greater clarity $\left(\mathrm{L}^{*}\right)$ and a darker yellow tone $\left(\mathrm{b}^{*}\right)$ than the green fruit which showed a greener color $\left(\mathrm{a}^{*}\right)$ (Table 1$)$.

The number of fruits per kilogram varied depending on size, stage of maturity, and water content. The mean number of fruits was $576 \pm 53$ units $\mathrm{kg}^{-1}$ in the green stage and $738 \pm 72$ units $\mathrm{kg}^{-1}$ in the mature stage.

Flours with the mean dry weights indicated in Table 2 were obtained from the fruit and leaf samples $(1 \mathrm{~kg})$ in their distinct stages of maturity. The flour obtained from the green fruit had a mean dry weight inferior to the mature fruit due to its higher water content. The green
Table 1. Weight and diameter (mean \pm SD) and color of Melia azedarach fruit according to stage of maturity.

\begin{tabular}{lcc}
\hline & \multicolumn{2}{c}{ Stage of fruit maturity } \\
\cline { 2 - 3 } Parameter & Green & Mature \\
\hline Weight, g & $5.20 \pm 0.19$ & $4.06 \pm 0.10$ \\
Diameter, mm & $14.0 \pm 0.5$ & $12.8 \pm 0.5$ \\
Color of fruit & & \\
L* & 50.9 & 60.3 \\
$\mathrm{a}^{*}$ & -20.7 & -17.6 \\
$\mathrm{~b}^{*}$ & 34.3 & 47.7 \\
\hline
\end{tabular}

$L^{*}$ : clarity; $a^{*}$ : spectrum from green to red; $b^{*}$ : spectrum between yellow and blue; SD: standard deviation.

fruit lost almost $60 \%$ of its water while the mature fruit only $44 \%$. The leaves had similar dry weights in both the juvenile and mature stages with 422 and $496 \mathrm{~g}$ respectively given that the humidity in both stages of development was similar (Table 2).

\section{Chemical analysis of the fruit and leaf}

The proportion of raw fiber detected was slightly higher $(3 \%)$ in the mature stage of the fruit due to the increase of this element in the ripening process. There were no significant differences in the contents of ashes, lipids, and proteins in the distinct stages of fruit maturity (Table 3).

The ash, protein and raw fiber contents in the leaves did not show differences in the stages of development. There was a decrease in the lipid content close to $60 \%$ from the juvenile to the mature stage (Table 3 ).

\section{Analysis of fruit polyphenols}

The greatest proportion of total tannins was concentrated in the green stage with $3.9 \mathrm{~g} \mathrm{~L}^{-1}$ while in the mature stage it was only $2.56 \mathrm{~g} \mathrm{~L}^{-1}$. Only three of the fourteen substances obtained in the analysis of low molecular weight phenolic compounds were identified. The rest did not match any of the tested patterns. The main compounds along with their respective retention times are shown in Table 4.

The profile of the constituent compounds for green and mature $M$. azedarach fruit can be observed in the chromatographies obtained in Figure 1. Among the

Table 2. Initial humidity and dry weight (mean \pm SD) after grinding Melia azedarach fruit and leaf according to the stage of maturity.

\begin{tabular}{lccccc}
\hline & \multicolumn{2}{c}{ Fruit } & & \multicolumn{2}{c}{ Leaf } \\
\cline { 2 - 3 } \cline { 5 - 6 } Parameter & Green & Mature & & Juvenile & Mature \\
\hline Initial humidity, \% & $59.6 \pm 1.25$ & $44.1 \pm 1.14$ & & $60.9 \pm 0.34$ & $57.0 \pm 1.32$ \\
Mean dry weight, g & $381 \pm 9$ & $522 \pm 13$ & & $422 \pm 6$ & $496 \pm 12$ \\
\hline
\end{tabular}

SD: standard deviation. 
compounds with the greatest relation in the fruit, only those corresponding to the 4,8 and 9 peaks (maximum points of absorbency at $280 \mathrm{~nm}$ ) were identified. The first could be a catechin and the others kaempherols (Mabry et al., 1970). The spectrums of the most important peaks are shown in Figure 2.

It was observed in the chromatographies (Figure 1) that compounds with retention time, shape, and similar absorption in both stages of maturity of the fruit could indicate that most of the molecules are present in the two stages of maturity. This can be observed when comparing peak 2 of the green stage with the molecule found in peak 11 of the mature stage. The same situation occurred between peaks 1 and 10,2 and 11, 3 and 12,5 and 13, 7 and 14 .

Given the results obtained, only two phenolic compounds were identified in a preliminary way, catechin and kaempherol which belong to the flavan-3-ols and the flavanol groups respectively. Both constitute a part of the compounds called flavonoids, a group to which Izco (1998) allocates part of the insecticidal effects of the plants. These compounds have a wide range of biological effects, including antioxidant effects (defense against oxidative stress), as well as antimicrobial, anti-inflammatory effects, and vasodilatory action (Urquiaga and Leighton, 2000; Kahkonen et al., 2001). The compounds identified in this study were mainly associated to taste, antioxidant and prooxidant qualities as mentioned by Pérez (2003) in a study of flavonoids developed to evaluate these antioxidant and pro-oxidant qualities in the compounds. It is suggested that this line of research be continued because it will allow acquiring knowledge about the compounds responsible for the insecticidal qualities of the M. azedarach fruits and thus contribute to the production of new botanical insecticides.

Table 3. Chemical analysis (mean \pm SD) of Melia azedarach fruit and leaf according to stage of maturity.

\begin{tabular}{lrrrrr}
\hline \multirow{2}{*}{ Analysis } & \multicolumn{2}{c}{ Fruit } & & \multicolumn{2}{c}{ Leaf } \\
\cline { 2 - 3 } \cline { 5 - 6 } \cline { 5 - 6 } Ashes & \multicolumn{1}{c}{ Green } & Mature & & Juvenile & \multicolumn{1}{c}{ Mature } \\
\cline { 2 - 3 } \cline { 5 - 6 } Proteins & $5.12 \pm 0.10$ & $4.40 \pm 0.06$ & & $13.14 \pm 0.02$ & $11.92 \pm 0.47$ \\
Lipids & $6.87 \pm 0.15$ & $5.98 \pm 0.56$ & & $6.60 \pm 0.32$ & $6.10 \pm 0.28$ \\
Raw Fiber & $5.23 \pm 0.17$ & $5.17 \pm 0.29$ & & $2.80 \pm 0.08$ & $1.08 \pm 0.10$ \\
NNE & $35.70 \pm 0.13$ & $38.68 \pm 0.93$ & & $10.94 \pm 0.33$ & $10.33 \pm 0.39$ \\
\hline
\end{tabular}

SD: standard deviation; NNE: non-nitrogenated extract.

Table 4. Low molecular weight phenolic compounds in Melia azedarach fruits.

\begin{tabular}{ccc}
\hline Peak No & Compound & $\begin{array}{c}\text { Retention time } \\
\text { min }\end{array}$ \\
\hline 1 & Unknown & 2.75 \\
2 & Unknown & 3.72 \\
3 & Unknown & 18.72 \\
4 & Catechin & 23.00 \\
5 & Unknown & 30.48 \\
6 & Unknown & 42.27 \\
7 & Unknown & 48.43 \\
8 & Kaempherol & 57.36 \\
9 & Kaempherol & 62.33 \\
10 & Unknown & 2.81 \\
11 & Unknown & 3.87 \\
12 & Unknown & 19.59 \\
13 & Unknown & 31.25 \\
14 & Unknown & 49.23 \\
\hline
\end{tabular}

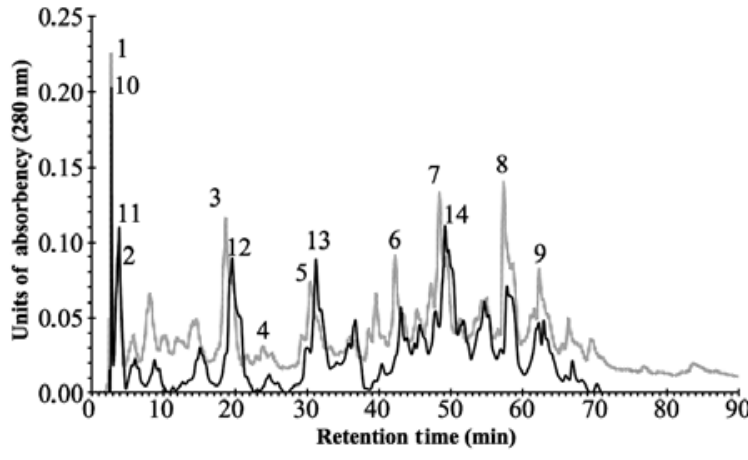

Figure 1. High-Performance Liquid Chromatography (HPLC) of the flour obtained from green and mature Melia azedarach fruit. 1-3, 5-7, 10-14: unknown; 4: catechin; 8-9: kaempherol. Green fruit (gray curve) and mature fruit (black curve). 


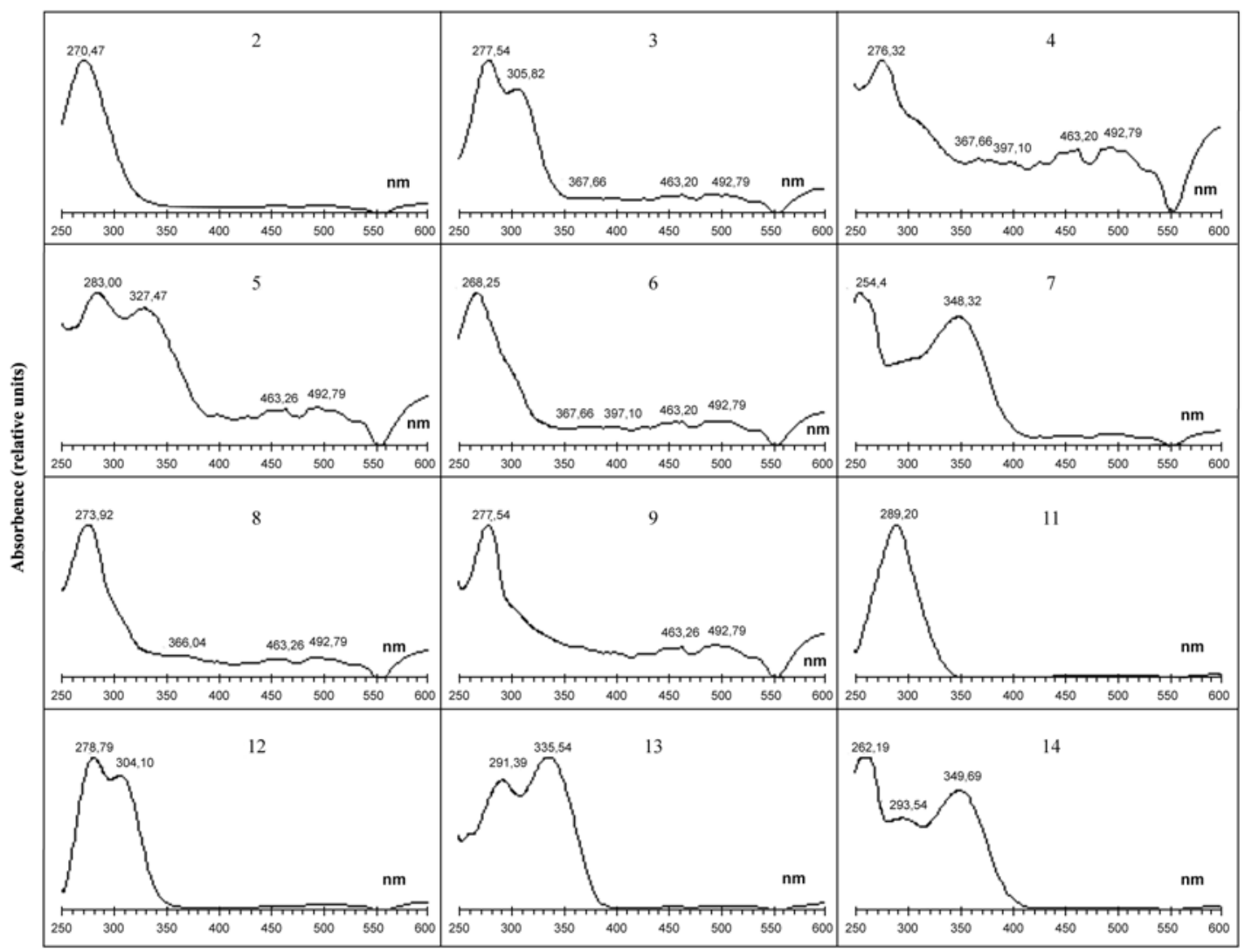

Wavelength (nm)

Figure 2. Spectrums of Melia azedarach fruit phenolic compounds. 2-3, 5-7, 11-14: unknown; 4: catechin; 8-9: kaempherol.

\section{Evaluation of the effectiveness of $M$. azedarach extracts}

The aqueous fruit and leaf extracts of M. azedarach in both stages of maturity affected the mortality of the adult D. melanogaster in a significant way $\mathrm{p} \leq 0.05$ (Tables 5 and 6).

The mortality of $D$. melanogaster attained with the green fruit extracts was higher than that obtained with mature fruits. The most effective results were obtained in the green fruit extracts with $10700 \mathrm{mg} \mathrm{kg}^{-1}$ and close to $74 \%$ mortality, followed by the extract concentration $7500 \mathrm{mg} \mathrm{kg}^{-1}$ (60\% mortality). The treatments with lower extract concentrations $\left(3200 \mathrm{mg} \mathrm{kg}^{-1}\right)$ of mature fruits caused a mortality rate close to $17 \%$ (Table 5 ).

Mortality of $D$. melanogaster by juvenile leaf extracts was greater than those obtained with the mature leaves. The most effective results were obtained with the juvenile leaf extracts with $125000 \mathrm{mg} \mathrm{kg}^{-1}$ and $90 \%$ mortality, followed by the extract concentrations of 75000 and $25000 \mathrm{mg} \mathrm{kg}^{-1}$ (70\% mortality). The treatments of the mature leaf extracts with a lower concentration (25000 $\mathrm{mg} \mathrm{kg}^{-1}$ ) caused a mortality rate of $60 \%$ (Table 6 ).
Tables 5 and 6 differentiate an effect of the extract concentrations on the mortality of the insects, i.e., a greater concentration of the product had a higher mortality rate independently of the stage of maturity of the fruit and leaves.

The behavior of $D$. melanogaster during the bioassays varied according to the stage of maturity evaluated and the concentration of the extract. Because the product was mixed with the food, the flies initially tended to descend towards the environment, but moved away as the days went by. This withdrawal of the flies from the breeding environment was most notorious in the treatments with the highest doses of extract where the flies descended to eat during the first 3 days and afterwards stayed in the upper part of the jar. The bioassays generally did not produce viable descendants of $D$. melanogaster. Some of the treated individuals produced insects which were incapable of developing or had wing malformations.

The repellent action of the extracts and the malformations of some individuals were also observed by Rodríguez and Vendramim (1998), thus proving that most of the substances with a $M$. azedarach base inhibit the 
Table 5. Mean mortality of adult Drosophila melanogaster caused by aqueous fruit extracts of Melia azedarach in the diet.

\begin{tabular}{lccc}
\hline \multirow{2}{*}{$\begin{array}{l}\text { Stage of } \\
\text { maturity }\end{array}$} & \multicolumn{3}{c}{ Concentrations (mg kg-1) } \\
\cline { 2 - 4 } & $\mathbf{3 2 0 0}$ & $\mathbf{7 5 0 0}$ & $\mathbf{1 0 7 0 0}$ \\
Green & $43.3 \pm 1.15 \mathrm{c}$ & $60.0 \pm 1.00 \mathrm{~b}$ & $73.3 \pm 0.58 \mathrm{a}$ \\
Mature & $16.7 \pm 1.15 \mathrm{c}$ & $36.7 \pm 1.15 \mathrm{~b}$ & $53.3 \pm 0.58 \mathrm{a}$ \\
\hline
\end{tabular}

Distinct letters in the rows indicate significant differences between concentrations according Tukey test $(\mathrm{p} \leq 0.05)$. SD: standard deviation.

action of the oxidases in the small intestine; the juvenile insect is converted into a pupa or abnormal adult, or else dies due to nutritional deficiency or interference of the physiological processes. These results of the effectiveness of $M$. azedarach insecticidal extracts coincide with those obtained by other authors, such as Valladares et al. (1997) and Defagó et al. (2006) who evaluated three ethanolic concentrations $(2,5$, and $10 \%)$ of $M$. azedarach in Argentina achieving mortality rates close to $100 \%$ in Xanthogaleruca luteola (Coleoptera: Chrysomelidae).

Vergara et al. (1997) indicate that the combined effects of the compound in the fruit are more powerful than individually. It can be inferred that an extract based on the whole fruit would be better than isolating the active principle given that if a set of compounds existed, not only would the mortality of the insects increase, but the probability would also decrease that these would develop resistance to a mixture of active ingredients. Islan (1997) points out that it is more difficult for the insects to react to a complex of substances than to a single molecule.

\section{CONCLUSIONS}

In accordance with the results obtained, it can be concluded that the diameter of the $M$. azedarach fruit was lower than the mean found in the literature. The chemical analysis of the fruit established a slight increase in the raw fiber content with an increment in the degree of maturity. There was a decrease in the quantity of lipids in the leaves close to $60 \%$ from the juvenile to the mature stage. In a preliminary analysis of $M$. azedarach fruit polyphenols, 14 compounds were found and three possible flavonoids were identified, one catechin and two kaempherols. The $M$. azedarach leaf and fruit extracts were effective as insecticides against $D$. melanogaster reaching mortality rates up to $90 \%$ in juvenile leaves $\left(125000 \mathrm{mg} \mathrm{kg}^{-1}\right)$ and $73.3 \%$ in green fruits $\left(10700 \mathrm{mg} \mathrm{kg}^{-1}\right)$. These results are promising considering that the plant material came from ornamental trees which were not under silvicultural management in order to take advantage of their insecticidal compounds.
Table 6. Mean mortality of adult Drosophila melanogaster caused by aqueous leaf extracts of Melia azedarach in the diet.

\begin{tabular}{lccc}
\hline \multirow{2}{*}{$\begin{array}{l}\text { Stage of } \\
\text { maturity }\end{array}$} & $\mathbf{2 5 0 0 0}$ & $\mathbf{7 5 0 0 0}$ & $\mathbf{1 2 5 0 0 0}$ \\
\cline { 2 - 4 } & \multicolumn{3}{c}{ Percentage \pm SD } \\
Juvenile & $70.0 \pm 2.30 \mathrm{~b}$ & $70.0 \pm 2.30 \mathrm{~b}$ & $90.0 \pm 1.48 \mathrm{a}$ \\
Mature & $60.0 \pm 1.73 \mathrm{c}$ & $66.7 \pm 2.35 \mathrm{~b}$ & $76.7 \pm 1.20 \mathrm{a}$ \\
\hline
\end{tabular}

Distinct letters in the columns indicate significant differences between concentrations according Tukey test $(\mathrm{p} \leq 0.05)$.

SD: standard deviation.

\section{ACKNOWLEDGEMENTS}

Research was financed by FONDECYT-Initiation DI 2006 (ESP-INI 06/01) Incentive Project of the Research Department of the University of Chile.

\section{RESUMEN}

Caracterización física y química del fruto y hoja de Melia azedarach $\mathbf{L}$. para uso como insecticida botánico. Se estudiaron las características físicas, químicas y las propiedades insecticidas del fruto y hojas de melia (Melia azedarach L.) (Meliaceae), árbol introducido con fines ornamentales en Chile. Se evaluaron las propiedades físicas y químicas de dos estados de madurez del fruto, verde y maduro, y de las hojas, juveniles y maduras. Las propiedades insecticidas se evaluaron mediante bioensayos de laboratorio sobre Drosophila melanogaster Meigen (Diptera: Drosophilidae), como insecto modelo. El diámetro del fruto de $M$. azedarach se situó en el límite inferior con referencia a otros estudios. La harina obtenida del fruto verde tuvo un peso seco promedio inferior al maduro. Las hojas tuvieron pesos secos promedio similares, tanto en el estado juvenil como en el maduro. Los frutos verdes tuvieron un contenido de humedad de $50 \%$, similar a las hojas juveniles $(60 \%)$ y maduras $(57 \%)$, pero mayor que los frutos maduros (44\%). El análisis químico de los estados de madurez del fruto determinó un aumento leve en el contenido de fibra cruda según aumentaba la madurez. En las hojas hubo una disminución cercana a $60 \%$ en la cantidad de lípidos cuando maduran. Además, un análisis de polifenoles, por HPLC-DAD (Cromatografía Líquida de Alta Resolución con Detector de Arreglo de Diodos) identificó 14 compuestos como causantes del efecto insecticida del fruto de M. azedarach, de los cuales tres corresponderían a flavonoides: una catequina y dos kaempferoles. Finalmente, los extractos acuosos de hojas y frutos de M. azedarach fueron eficaces como insecticidas sobre D. melanogaster, alcanzando 
mortalidades de hasta $90 \%$ con hojas juveniles (125000 $\mathrm{mg} \mathrm{kg}^{-1}$ ) y $73,3 \%$ con frutos verdes $\left(10700 \mathrm{mg} \mathrm{kg}^{-1}\right)$.

Palabras clave: árbol del paraíso, Meliaceae, compuestos fenólicos.

\section{LITERATURE CITED}

AOAC. 1984. Official methods on analysis of the Association of Official Analytical Chemists. 14 $4^{\text {th }}$ ed. 1.141 p. Association of Official Analytical Chemists (AOAC), Washington, D.C., USA.

Bate-Smith, E. 1981. Astringent tannins of the leaves of Germain species. Phytochem. 20:211-216.

Carpinella, C., T. Defago, G. Valladares, and M. Palacios. 2003. Antifeedant and insecticide properties of a limonoid from Melia azedarach (Meliaceae) with potential use for pest management. J. Agric. Food Chem. 51:369-374.

Carpinella, M.C., C.G. Ferrayoli, and S.M. Palacios. 2005. Antifungal synergistic effect of scopoletin, a hydroxycoumarin isolated from Melia azedarach L. fruits. J. Agric. Food Chem. 53:2922-2927.

Defagó, M., G. Valladares, E. Banchio, C. Carpinella, and S. Palacios. 2006. Insecticide and antifeedant activity of different plant parts of Melia azedarach on Xanthogaleruca luteola. Fitoterapia 77:500-505.

González-Gómez, R., G. Otero-Colina, J.A. VillanuevaJiménez, J.A Pérez-Amaro, y R.M. Soto-Hernández. 2006. Toxicidad y repelencia de Azadirachta indica contra Varroa destructor (Acari: Varroidae). Agrociencia 40:741-751.

Hoffmann, A. 1995. Los árboles urbanos de Chile. Fundación Claudio Gay, Santiago, Chile.

Hunter Labs. 1996. Hunter lab color scale. Insight on color 8(9). Hunter Associates Laboratories, Reston, Virginia, USA.

Islan, B. 1997. Neem and other botanical insecticides: barriers to commercialization. Phytoparasitica 25:339344.

Isman, M.B. 1999. Pesticides based on plant essential oils. Pestic. Outlook 10:68-72.

Izco, J. 1998. Caracteres taxonómicos: Composición química. Botánica. p. 155-172. McGraw-HillInteramericana, Madrid, España.

Kahkonen, M., A. Hopia, and M. Heinonen. 2001. Berry phenolics and their antioxidant activity. J. Agric. Food Chem. 49:4076-4082.

Mabry, T.J., K.R. Markham, and M.B. Thomas. 1970. The systematic identification of flavonoids. $354 \mathrm{p}$. Springer-Verlag, Berlin, Germany.
Mazzonetto, F., and J. Vendramim. 2003. Effect of powders from vegetal species on Acanthoscelides obtectus (Say) (Coleoptera: Bruchidae) in stored bean. Neotrop. Entomol. 32:145-149.

Moreno, M., S. González, I. Acevedo, G. Morales, M. Betancour, J. López, y C. Peláez. 2000. Drosophila melanogaster (Diptera: Drosophilidae): modelo biológico para la estandarización de extractos naturales con actividad insecticida. Rev. Colombiana Entomol. 26(1-2):41-47.

Ngo, T., R.E. Wrolstad, and Y. Zhao. 2007. Color quality of Oregon strawberries- Impact of genotype, composition, and processing. J. Food Sci. 72(1): C025-C032.

Padrón, B., A. Oranday, C. Rivas, y M. Verde. 2003. Identificación de compuestos de Melia azedarach, Syzgium aromaticum y Cinnamomum zeylanicum con efecto inhibitorio sobre bacterias y hongos. Ciencia UANL 6(3):333-338.

Peña, A., T. Hernández, C. García-Vallejo, I. Estrella, and J.A. Suárez. 2000. A survey of phenolic compounds in Spanish wines from different geographical origins. Eur. Food Res. Technol. 210:445-448.

Pérez, G. 2003. Los flavonoides: antioxidantes o prooxidantes. Rev. Cubana Invest. Biomed. 22(1):48-57.

Pérez-Pacheco, R., C. Rodríguez, J. Lara-Reyna, R. Montes, y G. Ramírez. 2004. Toxicidad de aceites, esencias y extractos vegetales en larvas del mosquito Culex quinquefasciatus (Say.) (Diptera: Culicidae). Acta Zool. Mex. Nueva Serie 20(1):141-152.

Perry, A.S., I. Yamamoto, I. Ishaaya, and R.Y. Perry. 1998. Insecticides in agriculture and environment: retrospects and prospects. 261 p. Springer-Verlag, Berlin, Germany.

Rodríguez, H. 1998. Determinación de toxicidad y bioactividad de cuatro insecticidas orgánicos recomendados para el control de plagas en cultivos hortícolas. Rev. Latinoamericana de Agricultura y Nutrición (RELAN) 1(3):32-41.

Rodríguez, H., y J. Vendramim. 1998. Uso de índices nutricionales para medir el efecto insectistático de extractos de meliáceas sobre Spodoptera frugiperda. Rev. Manejo Integrado de Plagas (Honduras) 48:1118.

SAS Institute. 1998. SAS. Language guide for personal computers release 6.03 Edition. 1028 p. SAS Institute, Cary, North Carolina, USA.

Schmutterer, H. (ed.) 2002. The neem tree. 892 p. Neem Found, Mumbai, India.

Thacker, J.R.M. 2002. An introduction to arthropod pest control. 343 p. Cambridge University Press, 
Cambridge, UK.

Urquiaga, I., and F. Leighton. 2000. Plant polyphenol antioxidants and oxidative stress. Biol. Res. 33:5564.

Valladares, G., M.T. Defagó, S.M. Palacios, and M.C. Carpinella. 1997. Laboratory evaluation of Melia azedarach (Meliaceae) extracts against the elm leaf beetle (Coleoptera: Chrysomelidae). J. Econ. Entomol.
90:747-750.

Vergara, R., C. Escobar, y P. Galeano. 1997. Potencial insecticida de extractos de Melia azedarach L. (Meliaceae). Actividad biológica y efectos. Rev. Fac. Nac. Agron. Medellín 50(2):186.

Villalobos, P. 1996. Plaguicidas naturales de origen vegetal: Estado actual de la investigación. 35 p. Instituto Nacional de Investigación y Tecnología Agraria y Alimentaria, Madrid, España. 